\title{
Family Resources, Peer Support, and Community Nutrition to Improve the Quality of Life Among Elderly
}

\author{
D Hanim ${ }^{1}$, A Lestari \\ ${ }^{1,2}$ Public Health Department, Medicine Faculty of Universitas Sebelas Maret, J1. Ir. Sutami No \\ 36 A, Kentingan, Jebres, Surakarta, Indonesia \\ ${ }^{1,2}$ Funded by Skim Grant: Prime Research Applied UNS (PUT-UNS) 2018 \\ ${ }^{1,2}$ Featured field: Human Development and National Competitiveness Institute for Research \\ and Community Service UNS \\ Email: diffah@staff.uns.ac.id
}

\begin{abstract}
Approach Social Determinants of Health and nutritional status is an important concept to improve the living conditions and quality of life conducive to the elderly (Elderly). For the 29th of May in Indonesia declared a National Elderly Day in order to build an organization of elderly people strong and independent so as to be a group of elderly people who can handle any kind of health and nutrition problems were able to find a solution aspiration elderly group. This study aimed to analyze the influence of determinant factors on the quality of life among elderly so that it can be a reference to the design of health and nutrition promotion models to improve Reviews their quality of life. This quantitative study was crosssectional design conducted in Surakarta, Central Java Province from March to September 2018. Methods, There were 122 elderly selected as research subjects. The dependent variables were nutritional status and the quality of life. The independent variables were age, education, income, behavior, family support, peer support, and the support of community nutrition. Data were collected using questionnaires and nutritional status Analyzed using path analysis. The result, The Quality of elderly life increases with increasing levels of education, income, positive behavior of community nutrition, and peer support. The quality of elderly life decreases with increasing age. Integrative nutrition and health promotion models to improve the quality of elderly life are designed by improving the role of peer support, increasing education, income and positive behavior of community nutrition. Conclusion, Family Resources, with a culture of healthy hygienic behavior and Peer Support, through religious activities and associations gathering and Community Nutrition to Improve the Quality of Life among Elderly shows there are many elderly people who smoke at home (46.2\%)
\end{abstract}

Keywords: Elderly; Peer Support; Integrative Nutrition; Health Promotion Models Improve The Quality Of Life 


\section{INTRODUCTION}

Social Capital of elderly empowerment is a way of thinking more broadly about the determinant factors of nutritional health of the elderly who live with their families and communities instead of in a nursing home [1]. Recently, World Population Prospects: The 2010 Revision shown the population of elderly in the world have drastically Increased however Reviews their quality of life decline with increasing age. The individual of the elderly is susceptible to degenerative diseases. Nowadays, there is still a big difference in the quality of elderly life between developed and developing countries. In developed countries, the elder people are still active, healthy, and productive so that they are still able to work and earn their own income. In opposite, the elderly in poor and developing countries such as Indonesia still need to be improved so that they will not be a burden for the family, society, and country. Life expectancy of Indonesia Year 2008 - 2015 and the Projection Year 2030-2035 shown 18\% of elderly had live expectation until more than 60 years old. This study aimed to analyze the influence of determinant factors on the quality of life among elderly so that it can be a reference to the design of health and nutrition promotion models to improve their quality of life. This quantitative study was cross-sectional design conducted in Surakarta, Central Java Province from March to September 2018.

Increased life expectancy in the world has resulted in changes in the structure and characteristics of the population drastically. The world's population becomes older, so residents over the age of 60 or 65 years with small amounts are increased. Analyze of the world around one in ten of the world's population is the elderly population aged 60 years or more. By 2050 the number of elderly will increase to five in ten of the world population, and one in three of the world population will be aged 60 years or more. About one in four in the middle of the 21 st century in some developed countries will reach one of the two population the aged over 60 years.

\section{METHOD}

The study uses a cross sectional of determinant nutrition and health elderly. The research can be categorized as quantitative research but relies more on in the interpretation of data. There were 222 elderly selected as research subjects. The dependent variables were nutritional status and the quality of life. The independent variables were age, education, income, behavior, family support, peer support, and the support of community nutrition. Data were collected using questionnaires and nutritional status Analyzed using path analysis.

\section{RESULT AND DISCUSSION}

There are still a lot of elderly people who smoke at home $(46.2 \%)$, elderly people who do not do physical activity / exercise regularly every day (86.6\%) and many elderly people who do not eat fruit and vegetables every day $(36.1 \%)$. The Quality of Life among Elderly The quality of life of elderly was positively correlated with $\geq$ senior high school education $(b=0: 44, \mathrm{SE}=$ $0: 44, p=0.568)$, income per month $\geq \operatorname{Rp} 1476.420(b=0.99 ; \mathrm{SE}<0.001 ; \mathrm{p}=0.235)$, positive behavior $b=3.57 ; \mathrm{SE}=0: 18 ; \mathrm{p}=0.039)$, and peer support $(\mathrm{b}=7: 35 ; \mathrm{SE}=0: 22 ; \mathrm{p}<0.001)$. The quality of elderly life shown a negative relationship with age $(b=-2.06 ; \mathrm{SE}=0: 35 ; \mathrm{p}=0.190)$ and community nutrition $(b=-2.07 ; \mathrm{SE}=0: 25 ; \mathrm{p}=0084)$. Quality of life elderly increases with increasing levels of education, income, positive behavior of community nutrition, and peer 
support. The quality of elderly life decreases with increasing age. Integrative nutrition and health promotion models to improve the quality of life of the elderly are designed by improving the role of peer support, increasing education, income and positive behavior of community nutrition.

Table 1. The Result of Subject Characteristics Analysis

\begin{tabular}{|c|c|c|c|c|c|c|c|c|c|c|}
\hline \multirow[t]{2}{*}{ Characteristics } & \multicolumn{9}{|c|}{ Groups } & \multirow{3}{*}{$\begin{array}{c}\text { P Value } \\
0,570\end{array}$} \\
\hline & \multicolumn{3}{|c|}{$\begin{array}{c}\text { Hypertension }(\mathrm{n}=81) \\
\text { Mean } \pm \mathrm{SD}\end{array}$} & \multicolumn{3}{|c|}{$\begin{array}{c}\text { Coronary heart } \\
\text { disease }(\mathrm{n}=81) \\
\text { Mean } \pm \mathrm{SD}\end{array}$} & \multicolumn{3}{|c|}{$\begin{array}{c}\text { Healthy } \\
(n=81) \\
\text { Mean } \pm \text { SD }\end{array}$} & \\
\hline Age (year) & 65,7 & \pm & 5,4 & 53,2 & \pm & 8,6 & 57,6 & \pm & 8,4 & \\
\hline BMI & 25,1 & \pm & 3,1 & 24,8 & \pm & 2,8 & 28,0 & \pm & 3,8 & 0,086 \\
\hline $\mathrm{BW}(\mathrm{kg})$ & 58,1 & \pm & 8,7 & 55,5 & \pm & 5,5 & 63,0 & \pm & 9,7 & 0,162 \\
\hline $\mathrm{H}(\mathrm{cm})$ & 152,0 & \pm & 5,0 & 149,7 & \pm & 3,5 & 149,9 & \pm & 4,6 & 0,453 \\
\hline Pre Cholesterol (mg/dl) & 242,7 & \pm & 24,7 & 251,7 & \pm & 25,1 & 145,8 & \pm & 32,6 & 0,077 \\
\hline LDL pre (mg/dl) & 169,9 & \pm & 23,6 & 173,6 & \pm & 28,4 & 121,9 & \pm & 19,9 & $0,044 *$ \\
\hline Tension /blood pressure & 169,9 & \pm & 10,6 & 153,6 & \pm & 18,4 & 131,9 & \pm & 29,9 & 0,054 \\
\hline Energy (Kkal) & 2542,9 & \pm & 427,5 & 2379,7 & \pm & 345,0 & 2254,4 & \pm & 576,5 & $0,041 *$ \\
\hline Fat $(\mathrm{g})$ & 136,4 & \pm & 34,9 & 157,1 & \pm & 19,0 & 106,7 & \pm & 37,5 & $0,050 *$ \\
\hline Carbohydrate (g) & 280,5 & \pm & 35,0 & 295,0 & \pm & 57,4 & 240,7 & \pm & 61,2 & 0,090 \\
\hline Fiber $(\mathrm{g})$ & 7,1 & \pm & 2,1 & 9,3 & \pm & 2,9 & 30,1 & \pm & 4,3 & 0,048 \\
\hline Vit. C (mg) & 59,1 & \pm & 37,4 & 96,4 & \pm & 73,2 & 41,9 & \pm & 24,8 & 0,073 \\
\hline
\end{tabular}

At the beginning of examination there were 243 elderly subjects, due to 21 elderly subjects did not take part in the research activities (lost follow up 9.45\%) so the data became incomplete. This means that there are $90.55 \%$ of the subjects who followed the completion study. Table 2 describes the distribution of research subjects according to health behavioral variables consisting of five elements, namely nutritional behavior, physical activity, early detection of disease, consumption of cigarettes and alcohol, and stress management.

Tabel 2. The results of nutritional elements and health behavior analysis $(n=222$ people)

\begin{tabular}{llllllll}
\hline No & $\begin{array}{l}\text { Elements of behavioral } \\
\text { variables }\end{array}$ & Mean & SD & Min & Max & $\begin{array}{l}\text { Achievements } \\
(\%)\end{array}$ & $\mathrm{p}$ \\
\hline 1 & Nutritional Behavior & 17.37 & 1.797 & 7 & 20 & 86.85 & 0.054 \\
\hline 2 & Physical activity & 4.82 & 0.877 & 1 & 6 & 80.33 & 0.048 \\
\hline 3 & $\begin{array}{l}\text { Early detection of } \\
\text { disease }\end{array}$ & 6.77 & 1.304 & 3 & 8 & 84.63 & 0.087 \\
\hline 4 & $\begin{array}{l}\text { Consumption of } \\
\text { cigarettes and alcohol }\end{array}$ & 5.63 & 0.642 & 3 & 6 & 93.83 & 0.050 \\
\hline 5 & Stress management & 5.27 & 0.793 & 3 & 6 & 87.83 & 0.91 \\
\hline
\end{tabular}

The elderly have balanced nutritional behavior with the habit of consuming red guava juice before breakfast at $169.9 \mathrm{mg} / \mathrm{dl} /$ person per day. this shows that the elderly who suffer from hypertension or coronary heart disease (Coroner Heart Disease) are aware of nutrition that drinking fruit juice or eating vegetables before breakfast will maintain a balance of blood profiles so that blood sugar and blood cholesterol level are controlled daily. Benefits of red guava fruit juice on changes in LDL levels and total cholesterol. Cholesterol has been shown to 
disrupt and alter the structure of blood vessels which results in impaired endothelial function that causes lesions, plaques, occlusion and embolism. Also cholesterol is thought to be responsible for increased oxidative stress [2]. Cholesterol in the food we eat can increase cholesterol levels in the blood which results in hypercholesterolemia [3]. One of the most common disease caused by increased cholesterol levels in the blood is atherosclerosis [4].

The mechanism of the occurrence of hypercholesterolemia is that fat derived from food will experience digestion in the intestine into free fatty acids, triglycerides, phospholipids, and cholesterol. Then absorbed in the form of kilomicron. The remainder of chylomicrons circulates towards the liver and is sorted into cholesterol. Some of this cholesterol is buried into bile as a bile acid and part of it together with triglycerides will ally with certain proteins (apoprotein) and form Very Low Density Lipoprotein (VLDL), which is further broken down by lipoprotein enzymes into Lipoprotein Density Intermediaries (LDI) which can not last 2-6 hours because it will immediately be converted into low density lipoprotein [5].

According to Utantio (2007), atherosclerosis is a change in the intima arterial variable which is a focal accumulation of fat (lipids), a complex of carbohydrates, blood, and fibrous tissue. Atherosclerosis is the most common cause of coronary heart disease, which is $98 \%$ while the rest is due to spasm and arterial abnormalities (2\%). The occurrence of narrowing of the corronary arteries begins with the occurence of atherosclerosis (arterial stiffnes) and those that have occurred accumulation of fat (plague) in the coronary artery wall, both accompanied by clinical symptoms or even without symptoms.

The results of this study are in accordance with Malekafzali, Eftekhari,Baradaran, et all, (2010) which shows red guava fruit juice has antihypertensive potential, so that it can be used by the public to prevent elevated cholesterol levels in the blood. The dose of $50 \mathrm{mg} / \mathrm{kg} \mathrm{BW}$ is converted to a human dose of $70 \mathrm{~kg}$ with a conversion factor of 0.018 equivalent to $400 \mathrm{mg}$. This results gave hopes of its use to prevent elevated LDL cholesterol in the blood.

The formation of LDL by receptors in controlling blood cholesterol. Inside the blood vessels there are destructive cells that can damage LDL. Through the pathways of these destructive cells the LDL molecule is oxidized, so it cannot re-enter the bloodstream. Cholesterol that is abundant in LDL will accumulate in destructive cells. If this happens for years cholesterol will accumulate in the walls of blood vessels and form plaques. The plaque will mix with protein and be covered by muscle cells and calcium. This is what can be developed later into atherosclerosis [6].

The behavior of physical activity on the subject based on table 2 showed that most subjects have good physical activity $67.40 \%$ or about $2 / 3$ of the total subjects while the remaining $32.60 \%$ or about $1 / 3$ of the subjects are less category. This is an accordance with the recognition of the subjects, most of them often do elderly gymnastics and walk regularly in the morning for 30 minutes. The type of exercise for the elderly light and an aerobic [7].

The behavior of early detection of disease in subjects based on table 2 turned out that most of the subjects had good early detection of disease $61.20 \%$, while the remaining $38.80 \%$ were categorized as less. This is an accordance with the recognition of the subjects, most of them routinely come to pre-elderly posyandu and elderly people every month, which is one of the activities carried out in pre-elderly and elderly posyandu is early detection of disease and monitoring of health conditions. The behavior of early detection of coronary heart disease in elderly smokers has been shown in 7 stages of health promotion, including elderly smokers must exercise regularly and consume vitamin C every day (WHO, 2017). 


\section{CONCLUSION}

Family Resources, with a culture of healthy hygienic behavior and Peer Support, through religious activities and associations gathering and Community Nutrition to Improve the Quality of Life among Elderly shows there are many elderly people who smoke at home (46.2\%), elderly people who do not do physical activity / exercise regularly every day $(86.6 \%)$ and many elderly people who do not eat fruit and vegetables every day (36.1\%).

\section{REFFERENCE}

[1] R. Machmud, N. Azkha, Masrul, R. Semiarti, D. Symond, and N. Silvia, Implementing Social Determinant of Health Through Social Capital \& Empowerment of The Jati Village To Reduce Inequalities In Health. Padang: Andalas University Press, 2012.

[2] P. A. Stapleton, A. G. Goodwill, M. E. James, R. W. Brock, and J. C. Frisbee, "Hypercholesterolemia and microvascular dysfunction: interventional strategies," $J$. Inflamm., vol. 7, no. 1, p. 54, 2010.

[3] S. Imam, Jantung Koroner dan Serangan Jantung. Jakarta: Gramedia Pustaka Utama, 2004.

[4] M. Maeda, T. Hayashi, N. Mizuno, Y. Hattori, and M. Kuzuya, "Intermittent High Glucose Implements Stress-Induced Senescence in Human Vascular Endothelial Cells: Role of Superoxide Production by NADPH Oxidase," PLoS One, vol. 10, no. 4, p. e0123169, Apr. 2015.

[5] L. Ma, J. Wang, and Y. Li, "Insulin resistance and cognitive dysfunction," Clin. Chim. Acta, vol. 444, pp. 18-23, Apr. 2015.

[6] C.-L. Liu et al., "Allergic lung inflammation promotes atherosclerosis in apolipoprotein E-deficient mice," Transl. Res., vol. 171, pp. 1-16, May 2016.

[7] B. S. Bender, "Infectious disease risk in the elderly.," Immunol. Allergy Clin. North Am., vol. 23, no. 1, pp. 57-64, Feb. 2003. 